\title{
EDITORIAL
}

\section{Check the FEV 1 for all adult smokers, even patients without respiratory symptoms}

See linked article by Miedinger et al. on page 163

\section{*Paul Enright \\ Professor of Medicine, The University of Arizona, Tucson, Arizona, USA \\ *Correspondence: \\ E-mail: lungguy@aol.coml}

Keywords: Spirometry, screening, case-finding, FEV 1, COPD, adults, smokers, symptoms

22nd May 2010
Clinical practice guidelines (CPGs) usually become more complicated over time, but new evidence - including a study published in this issue of the PCR ${ }^{1}$ - makes COPD casefinding easier and much more efficient. The forced expiratory volume in one second $\left(F V_{1}\right)$ should be measured using an inexpensive pocket spirometer for all smokers aged 40 and over, regardless of the presence or absence of respiratory symptoms. Only the one patient in eight with a low $\mathrm{FEV}_{1}$ then needs pre- and post-bronchodilator spirometry to confirm clinically-important COPD.

More than 30,000 spirometry tests were done by 440 Swiss GPs for their currentlysmoking patients, ${ }^{2}$ as recommended by many CPGs. Of those with good quality spirometry and short respiratory questionnaires, about 13\% had clinically-important COPD for which inhaler treatment might be considered (a low $\mathrm{FEV}_{1} /$ forced vital capacity (FVC) ratio, and $\mathrm{FEV}_{1}$ below $65 \%$ predicted), but these patients were no more likely than the others to report cough, phlegm, wheeze, or dyspnoea. As confirmed by other investigators, ${ }^{3}$ the COPD screening questionnaires developed and advertised by drug manufacturers $\mathrm{s}^{4-6}$ provided no value in primary care settings beyond knowledge of smoking status and age. These questionnaires may help to promote "COPD awareness" (and increase inhaler sales) when published in the popular media, but some smokers without worrisome respiratory symptoms may falsely conclude that they are not at increased risk of having COPD.

About a quarter of adult smokers in the Swiss study reported that they became short of breath when hurrying or walking up a slight hill. ${ }^{1}$ This corresponds to Grade 2 on the M edical Research Council (MRC) dyspnoea scale. However, the same percentage of Swiss patients reported this level of dyspnoea when spirometry was entirely normal or when spirometry showed moderate to severe airway obstruction. This suggests that performing spirometry only for patients who report dyspnoea on exertion is not helpful for detecting COPD. Of course, smokers who have slowly developed very severe COPD (FEV 1 below about 1 litre) are likely to report having to stop to catch their breath after walking a few minutes on level ground (MRC Grade 4), but only $1 \%$ of adult smokers had this degree of impairment.

Most of the Swiss GPs found it difficult to obtain diagnostic-quality spirometry tests more than $80 \%$ of the time. ${ }^{2}$ Only about $40 \%$ of the tests met relaxed quality goals (at least three acceptable manoeuvres with the highest two $\mathrm{FEV}_{1} \mathrm{~S}$ matching within $200 \mathrm{~mL}$ ). The standardised spirometry quality goals include $\mathrm{FEV}_{1}$ repeatability within $150 \mathrm{~mL}^{7,8}$ Between $80 \%$ and $90 \%$ of tests done by experienced technologists meet these goals,, 910 demonstrating that the standards are realistic.

Obtaining good quality spirometry tests at each exam is essential when comparing the results from one visit to the next to determine if a clinically-important change in lung function has occurred due to treatment (or disease progression). However, when the results will be used only to determine the presence or absence of clinically-important airway obstruction - as when screening for COPD in smokers - tests with suboptimal quality can still be useful in some cases. For example, even if all of the manoeuvres stop too soon (causing the FVC to be under-reported), when the $\mathrm{FEV}_{1}$ is within the normal range COPD is ruled out (but not asthma). When a pocket spirometer or peak expiratory flow (PEF) meter is used in the first stage of COPD screening, poor quality manoeuvres may cause a falsely low $\mathrm{FEV}_{1}$ or PEF, but these results are not used to make a diagnosis. ${ }^{11-13}$ Instead, the low 
values prompt the patient to be referred to the second stage where optimal quality pre- and post-bronchodilator spirometry is done by experienced technologists.

Some "key opinion leaders" call for early detection of COPD, with $\mathrm{FEV}_{1} / \mathrm{FVC}<0.70$ and $\mathrm{FEV}_{1}$ values within the normal range; ${ }^{14}$ but evidence has accumulated that these smokers do not have an increased risk of dyspnoea, respiratory morbidity or mortality. ${ }^{15-17}$ COPD does not become clinically important until the $\mathrm{FEV}_{1} / \mathrm{FVC}$ ratio is below the age-corrected fifth percentile ${ }^{18}$ and $\mathrm{FEV}_{1}$ below about $65 \%$ predicted (in the middle of GOLD stage 2). Spirometry must be used to confirm clinically-important COPD in smokers with dyspnoea before a prescription for a daily COPD inhaler is considered, ${ }^{19}$ because dyspnoea is often due to factors other than airway obstruction in adult smokers.

\section{Conflict of interest declaration}

None.

\section{References}

1. Miedinger D, Linz A, Praehauser C, et al. Patient-reported respiratory symptoms and pre-bronchodilator airflow limitation among smokers in Switzerland. Prim Care Resp J (2010);19(2):163-9. http://dx.doi.org/ 10.4104/pcrj.2010.00030

2. Leuppi JD, Miedinger D, Chhajed PN, et al. Quality of spirometry in primary care for case finding of airway obstruction in smokers. Respiration 2009; 79(6):469-74. http://dx.doi.org/10.1159/000243162

3. Kotz D, Nelemans $P$, van Schyack CP, Weseling GJ. External validation of a COPD diagnostic questionnaire. Eur Respir J 2008;31:298-303. http://dx.doi.org/10.1183/09031936.00074307

4. Price DB, Tinkelman DG, Halbert RJ, et al. Symptom-based questionnaire for identifying COPD in smokers. Respiration 2006;73:285-95. http://dx.doi.org/ 10.1159/000090142

5. Martinez FJ, Eaczek AT, Seifer FD, et al. Development and initial validation of a self-scored COPD population screener questionnaire. COPD 2008;5:85-95. http://dx.doi.org/10.1080/15412550801940721

6. COPD Population Screener. http://www.drive4copd.com/copd-screener/ screener.aspx Accessed May 22, 2010

7. Miller MR, Hankinson J, Brusasco $V$, et al. Standardisation of spirometry. Eur Respir J 2005;26:319-38. http://dx.doi.org/10.1183/09031936.05.00034805

8. Levy ML, Quanjer PH, Booker R, Cooper BG, Holmes S, Small I. Diagnostic spirometry in primary care: Proposed standards for general practice compliant with American Thoracic Society and European Respiratory Society recommendations: a General Practice Airways Group (GPIAG) document, in association with the Association for Respiratory Technology \& Physiology (ARTP) and Education for Health. Prim Care Resp J 2009;18:130-47. http://dx.doi.org/10.4104/pcrj.2009.00054

9. Enright PL, Skloot GS, Cox-Ganser JM, Udasin IG, Herbert R. Quality of spirometry performed by 13,599 participants in the World Trade Center Worker and Volunteer Medical Screening Program. Respir Care 2010;55:1-7.

10. Castillo D, Guayta R, Giner J, et al. COPD case-finding by spirometry in highrisk customers of urban community pharmacies: a pilot study. Respir Med 2009;103(6):839-45. http://dx.doi.org/10.1016/j.rmed.2008.12.022

11. Rytila $P$, Helin $T$, Kinnula V. The use of microspirometry in detecting lowered FEV1 values in current or former cigarette smokers. Prim Care Resp J 2008; 17:232-7. http://dx.doi.org/10.3132/pcrj.2008.00058

12. Perez-Padilla R, Vollmer WM, Vázquez-García JC, Enright PL, Menezes AM, Buist AS; BOLD and PLATINO Study Groups Can a normal peak expiratory flow exclude severe chronic obstructive pulmonary disease? Int J Tuberc Lung Dis 2009;13(3):387-93.

13. Enright P. Over $90 \%$ of smokers don't need an expensive inhaler. Prove it by using a pocket spirometer. Eur Respir Society buyers guide to respiratory care products 2010. http://www.ersbuyersguide.org/uploads/Document/fa/ WEB_CHEMIN_5040_1252514654.pdf Accessed May 22, 2010

14. Tinkelman DG, Price D, Nordyke RJ, Halbert RJ. COPD screening efforts in primary care: what is the yield? Prim Care Resp J 2007;16:41-8. http://dx.doi.org/10.3132/pcrj.2007.00009

15. Schermer TR, Smeele IJ, Thoonen BP, et al. Current clinical guideline definitions for airflow obstruction leads to substantial overdiagnosis of COPD in primary care. Eur Resp J 2008;32(4):945-52. http://dx.doi.org/10.1183/ 09031936.00170307

16. Vollmer WM, Gíslason T, Burney $\mathrm{P}$, et al. Comparison of spirometry criteria for the diagnosis of COPD: results from the BOLD study. Eur Respir J 2009;34(3):588-97. http://dx.doi.org/10.1183/09031936.00164608

17. Vaz Fragoso CA, Concato J, McAvay G, et al. The ratio of FEV1/FVC as a basis for establishing chronic obstructive pulmonary disease. Am J Respir Crit Care Med 2010; in press. Published on December 17, 2009 as http://dx.doi.org/10.1164/rccm.200909-13660C.

18. Stanojevic S, Wade A, Stocks J, et al. Reference ranges for spirometry across all ages. A new approach. Am J Respir Crit Care Med 2008;177:253-60. http://dx.doi.org/10.1164/rccm.200708-12480C

19. Enright P, Quanjer P. Don't diagnose mild COPD without confirming airway obstruction after an inhaled bronchodilator. COPD 2007;4(2):89-90. http://dx.doi.org/10.1080/15412550701341509 